\title{
Financial Performance Evaluation of Listed Companies in Anhui Province Based on Principal Component Analysis
}

\author{
Yidan Liu, Qiuli Wu, Fang Yuan \\ Anhui University of Finance and Economics, Bengbu, China \\ Email: LiuYidan@163.com
}

How to cite this paper: Liu, Y. D., Wu, Q. L., \& Yuan, F. (2020). Financial Performance Evaluation of Listed Companies in Anhui Province Based on Principal Component Analysis. Open Journal of Social Sciences, 8, 293-303.

https://doi.org/10.4236/jss.2020.85021

Received: May 3, 2020

Accepted: May 23, 2020

Published: May 26, 2020

Copyright (c) 2020 by author(s) and Scientific Research Publishing Inc. This work is licensed under the Creative Commons Attribution International License (CC BY 4.0).

http://creativecommons.org/licenses/by/4.0/

\begin{abstract}
With the rapid development of economy, enterprises, as the micro-foundation and economic cells of urban economic vitality, have made great contributions to the development of social economy. And good financial performance management can help enterprises to operate and develop more efficiently and at a high level. This article selects the 56 listed companies in Anhui province as the research target of financial performance evaluation. From four aspects of profitability, development ability, operation ability and solvency including 15 indicators, then use principal component analysis (PCA) for comprehensive evaluation of enterprises' financial performance from two aspects of qualitative and quantitative to build the index system of enterprise financial performance, and on this basis put forward certain suggestions on the development of enterprises, investors and management for the enterprise to provide decision-making basis.
\end{abstract}

\section{Keywords}

Listed Companies in Anhui Province, Financial Performance Evaluation, Principal Component Analysis

\section{Introduction}

With the rapid development of economy, enterprises, as the micro-foundation and economic cell of urban economic vitality, have made great contributions to the expansion of investment, expansion of productivity development scale and improvement of productivity development level. Therefore, the steady and high-quality development of enterprises can better promote the development of the overall economy. Financial performance management is an important part of 
enterprise management, is the core of enterprise management, and directly affects the operation and development of enterprises. With the development of market economy, enterprises have more strict requirements on financial management. Therefore, it is very necessary to explore the financial performance management of enterprises to help them develop better.

Financial performance is the contribution that corporate strategy and its implementation and execution are making to the ultimate operating performance. Financial performance can fully express the effect of cost control, the effect of asset utilization and management, the effect of capital source allocation and the composition of the rate of return on shareholders' equity. Therefore, financial performance evaluation plays an increasingly important role in enterprise management. Through the exploration and analysis of the enterprise's financial performance, the factors affecting the enterprise's financial performance are sorted out, and then specific suggestions are provided for improving the operation level of enterprise's financial performance. It is helpful for enterprises to find their own positioning, make up for the shortcomings of the financial system, give play to their advantages, and manage their financial performance more accurately. Reasonable and effective financial performance management can provide good development conditions for enterprises, and help them to achieve stable and high-quality economic development.

\section{Literature Review}

As enterprises make more and more outstanding contributions in the process of economic development, many scholars have also studied the impact of financial performance management on enterprise development.

Cheng Lamei et al. (2020) took the back-door listing of SF Express as a case study, calculated the EVA value of SF Express group, and used the obtained EVA value to evaluate and analyze the financial performance of SF Express group before and after its listing. Cui Mengyuan, \& Huang Qian (2019) established the financial risk early warning model through principal component analysis, and divided the financial risks of 76 enterprises, realized the early warning analysis of the financial risk of enterprises, and established the financial risk early warning index system that can reflect the investment, financing, operation, debt repayment, profit and development ability. Li Hongrui, \& Wang Honghai (2020) to extract the 18 port as the research target of financial performance evaluation of listed companies, and global principal component analysis (PCA) is adopted to calculate and comprehensive scores and sorting, based on the analysis of the results of the study and interpretation, and proposes the corresponding improvement strategies, the study for the master port operating conditions which have certain reference significance for the future business decisions. Liu Jinfang, \& Duan Ruyue (2020) the text analyzes the new period under the enterprise financial performance evaluation index system on the implementation of the status quo, this paper expounds the new period, the enterprise financial performance indicators evaluation system to carry out the necessity of Liu Xuanting et al. 
(2020) on the basis of traditional enterprise financial evaluation system, the introduction of low carbon environmental protection related indicators, from two aspects of quantitative and qualitative build financial evaluation index system. Lu Yang, Wang Jingjing, Gao Kaili, \& Liu Xiaohui (2019) selected the data of listed companies in Jiangsu Province in 2017, used principal component analysis to quantify the growth of enterprises from four dimensions of profitability, cash flow capacity, operation capacity and development capacity, and analyzed the impact of R\&D investment on growth through multiple linear regression. The empirical conclusion shows that the higher the R\&D investment intensity, the better the growth of enterprises. Xie Hong, Xue Qianyu, \& Zhu Jia-ming (2019) in view of the small and medium-sized enterprise financing problems, to small and medium-sized enterprises in Jiangxi Province as the research object, made a comprehensive assessment of its financing ability and influence factors of quantitative analysis. First of all, from seven aspects to construct the financing capacity of containing 18 indexes evaluation index system, and by using the principal component analysis (PCA) in Jiangxi Province small and medium-sized enterprise financing ability of comprehensive evaluation. Yang Zihui, Wang Rao, Li Han, Zhang Litong, \& Wang Jiawei (2016) focused on the construction and influence of principal component analysis on the performance evaluation system of three types of state-owned enterprises. Based on the construction of different evaluation models and the inclusion of macro-economic indicators of the three types of enterprises by principal component analysis, it is found that the comprehensive ranking of economic competitive enterprises and the ranking of the same industry are slightly higher than the other two types of enterprises. Zhao Jinjin (2019) took Tsingtao Beer as an example, analyzed the strategic map of the company and evaluated its financial performance.

Based on the researches of several scholars on enterprise financial performance management evaluation, it is found that there are researches on the influencing factors of enterprise financial performance evaluation and related researches on enterprises in Anhui Province. However, there are relatively few studies on the combination of the two, and few studies on the application of this research idea to listed companies in Anhui Province. Therefore, this paper takes the listed companies in Anhui Province, whose development is not particularly prominent, as the research scope, comprehensively explores the impact of various indicators on the financial performance of listed companies in Anhui Province, and gives relevant suggestions.

\section{Financial Performance Evaluation System of Listed Companies}

\subsection{Selection of Indicators and Data Sources}

In this paper, listed companies in Anhui Province in 2019 were selected as research samples, and appropriate screening was carried out. Enterprises with incomplete data were excluded from the screening conditions, and ST enterprises were deleted. After screening, relevant data of 56 listed companies were finally 
obtained for research, all of which were from flush software.

The basis of profitability assessment is the growth rate of economic value added (EVA) and sales (profit). EVA is used to replace the previous return on equity, return on total assets, earnings per share and other indicators. The evaluation of enterprise profitability can better reflect the status of net capital income and capital appreciation, which is the development trend of the improvement of enterprise performance evaluation indicators. Use the sales revenue (profit) growth rate index to measure the enterprise growth, namely the ability to develop. Operating capacity can promote enterprises to strengthen asset management, improve the efficiency of asset use, and enhance profitability. The main evaluation indexes include inventory turnover, accounts receivable turnover and fixed assets turnover. The strength of debt paying ability is the main embodiment of the economic strength and financial condition of an enterprise, and it is also an important measure to measure whether an enterprise is operating steadily. The main indicators include asset-liability ratio, current ratio and quick ratio. This article from the profitability, development ability, operation ability and solvency four aspects included 56 the return on net assets, the net interest rate of the total assets of listed companies, sales, gross margin, sales net interest rate, basic earnings per share (year-on-year growth rate), operating income (year-on-year growth rate), operating profit (year-on-year growth rate), accounts receivable turnover, inventory turnover, total assets turnover ratio, current asset turnover and current ratio, quick ratio, cash ratio, asset-liability ratio for the 15 elements such as index, as Table 1.

Table 1. Evaluation factors and indicators.

\begin{tabular}{|c|c|}
\hline The evaluation factors & indicators \\
\hline \multirow{4}{*}{ profitability } & Return on equity \\
\hline & Net interest rate on total assets \\
\hline & Gross profit margin \\
\hline & Net interest rate on sales \\
\hline \multirow{3}{*}{ Development capacity } & Underlying earnings per share (year-on-year growth rate) \\
\hline & Operating income (year-on-year growth rate) \\
\hline & Operating profit (year-on-year growth rate) \\
\hline \multirow{4}{*}{ Operation ability } & Accounts receivable turnover \\
\hline & Inventory turnover \\
\hline & Total asset turnover \\
\hline & Current asset turnover \\
\hline \multirow{4}{*}{ Debt paying ability } & Current ratio \\
\hline & Quick ratio \\
\hline & Cash ratio \\
\hline & Asset-liability ratio \\
\hline
\end{tabular}




\subsection{Data Processing}

Excel was used to sort out the collected data, and SPSS was used to process the variable data. The descriptive statistics after the variable processing are shown in Table 2.

\subsection{Establishment and Solution of the Model}

\subsubsection{Correlation Test}

The 12 indexes selected in this paper are both relatively independent and correlated to some extent. Table 3 is the correlation coefficient matrix after the normalization of each index.

1) Calculate the correlation coefficient of each index.

2) Calculate the characteristic value and the contribution rate of each main factor.

The eigenvalue $\lambda_{i}$ is obtained by the vector inner product of the correlation coefficient matrix $(R)$, and the corresponding eigenvector $I_{i j}$ is obtained by the inverse compact transformation. Then the number of principal factors is determined according to the cumulative percentage of eigenvalues and the contribution rate of each principal factor is calculated.

Table 2. Descriptive statistics.

\begin{tabular}{|c|c|c|c|c|c|}
\hline \multicolumn{6}{|c|}{ Descriptive statistics } \\
\hline & $\mathrm{N}$ & The minimum & The maximum & The average & The standard deviation \\
\hline Return on equity & 56 & -58.16 & 56.52 & 10.0643 & 13.47936 \\
\hline Net interest rate on total assets & 56 & -45.79 & 26.07 & 5.6422 & 9.26309 \\
\hline Gross profit margin & 56 & 4.48 & 86.57 & 28.8081 & 20.21892 \\
\hline Net interest rate on sales & 56 & -98.87 & 45.58 & 8.2255 & 17.65041 \\
\hline Underlying earnings per share (year-on-year growth rate) & 56 & -81.02 & 208.57 & 28.8061 & 59.98186 \\
\hline Operating income (year-on-year growth rate) & 56 & -31.34 & 73.3 & 13.124 & 20.2325 \\
\hline Operating profit (year-on-year growth rate) & 56 & -77.35 & 333.96 & 38.6611 & 75.55239 \\
\hline Accounts receivable turnover & 53 & 1 & 244 & 21.14 & 41.011 \\
\hline Inventory turnover & 54 & 0.12 & 416.05 & 18.7928 & 63.6608 \\
\hline Total asset turnover & 56 & 0.09 & 2.26 & 0.8069 & 0.43826 \\
\hline Current asset turnover & 56 & 0.2 & 4.86 & 1.5579 & 0.95931 \\
\hline Current ratio & 56 & 0.48 & 8.65 & 2.16 & 1.78491 \\
\hline Quick ratio & 56 & 0.15 & 8.27 & 1.5165 & 1.46621 \\
\hline Cash ratio & 56 & 13.71 & 659.35 & 97.5272 & 122.5041 \\
\hline Asset-liability ratio & 56 & 10.47 & 90.38 & 43.3668 & 20.3863 \\
\hline
\end{tabular}

From the flush software. 





In the process of factor extraction using SPSS software, gravel parallel analysis method was used to select factors with eigenvalue greater than 1 . As can be seen from Table 3, there are 5 factors with eigenvalue greater than 1 , which are respectively represented by $Z 1, Z 2, Z 3, Z 4$ and $Z 5$, as Figure 1 .

SPSS software was used for principal component analysis, and the contribution rate of the principal factor was shown in Table 4. The top five main factor contribution amount to $84.027 \%$, the principle of combining with eigenvalues greater than 1 took five principal components and its characteristic values were $4.649,2.961,1.997,1.814,1.184$. The variance contribution rates of each principal component were $30.993 \%, 50.73 \%, 64.042 \%, 76.133 \%$ and $84.027 \%$, respectively. The accumulation contribution rate reached $84.027 \%$, indicating that the five principal components could represent the measured financial performance indicators of 56 listed companies. Therefore, the first five principal components were selected as the main factors to represent the information of $84.027 \%$ of the financial performance system of listed companies.

3) Calculate the factor load.

Calculate $R$ analysis factor load quantity $(L): L_{i j}=\sqrt{\lambda_{i} I_{i j}}$ of main factor $\left(P_{k}\right)$ and evaluation factor $\left(X_{j}\right)$, and further consider factor load quantity: $H_{i j}=L_{i j} P_{j}(j=1,2,3 \cdots, 12)$ of the case of relative importance of main factor. The factor load quantity is shown in Table 4 .

Note that the equation As can be seen from Table 5, the indexes that determine the size of the first principal component are the current ratio, the quick ratio and the cash ratio respectively. The indexes that determine the size of the second principal component are returned on equity and net interest rate on total assets. The indexes that determine the size of the third principal component are basic earnings per share and operating profit respectively. The indexes that determine the size of the fourth principal component are total asset turnover and current asset turnover. The indicators that determine the size of the fifth principal component are accounts receivable turnover and inventory turnover, respectively. Comprehensive analysis of the five principal components, the following principles of establishing index system and the principle of cause and effect, the first principal component can be named as the short-term debt paying ability of comprehensive index of listed companies, the second principal component named the profitability of the comprehensive index of listed companies, will be the third principal component named the development ability of comprehensive index of listed companies, the fourth and fifth principal component named the operation ability of comprehensive index of listed companies.

\subsection{Establishment of Financial Performance Evaluation System of Listed Companies}

1) By dividing the principal component load of each index variable by the eigenvalue of the principal component by the square root of the square root, the corresponding coefficients of each index of the five principal components are 
obtained, and the resulting coefficients are used as the weight to construct five principal component factor expressions:

$$
\begin{aligned}
Z 1= & 0.478 X 1+0.582 X 2+0.705 X 3+0.657 X 4-0.143 X 5 \\
& +0.213 X 6-0.101 X 7-0.243 X 8+0.051 X 9-0.389 X 10 \\
& -0.508 X 11+0.877 X 12+0.842 X 13+0.828 X 14-0.664 X 15
\end{aligned}
$$



\begin{tabular}{|c|c|c|c|c|c|c|c|c|c|}
\hline \multicolumn{10}{|c|}{ Total variance explanation } \\
\hline \multirow[t]{2}{*}{ Composition } & \multicolumn{3}{|c|}{ Initial eigenvalue } & \multicolumn{3}{|c|}{ Extract the sum of the squared loads } & \multicolumn{3}{|c|}{$\begin{array}{l}\text { The sum of the squares } \\
\text { of the rotational loads }\end{array}$} \\
\hline & total & $\begin{array}{l}\text { Percentage } \\
\text { of variance }\end{array}$ & $\begin{array}{c}\text { The } \\
\text { cumulative \% }\end{array}$ & total & $\begin{array}{l}\text { Percentage of } \\
\text { variance }\end{array}$ & $\begin{array}{c}\text { The } \\
\text { cumulative \% }\end{array}$ & total & $\begin{array}{l}\text { Percentage } \\
\text { of variance }\end{array}$ & $\begin{array}{c}\text { The } \\
\text { cumulative \% }\end{array}$ \\
\hline 1 & 4.649 & 30.993 & 30.993 & 4.649 & 30.993 & 30.993 & 3.744 & 24.96 & 24.96 \\
\hline 2 & 2.961 & 19.737 & 50.73 & 2.961 & 19.737 & 50.73 & 3.254 & 21.694 & 46.654 \\
\hline 3 & 1.997 & 13.311 & 64.042 & 1.997 & 13.311 & 64.042 & 2.005 & 13.366 & 60.02 \\
\hline 4 & 1.814 & 12.091 & 76.133 & 1.814 & 12.091 & 76.133 & 1.928 & 12.851 & 72.87 \\
\hline 5 & 1.184 & 7.894 & 84.027 & 1.184 & 7.894 & 84.027 & 1.674 & 11.157 & 84.027 \\
\hline 6 & 0.737 & 4.912 & 88.939 & & & & & & \\
\hline 7 & 0.601 & 4.008 & 92.947 & & & & & & \\
\hline 8 & 0.335 & 2.232 & 95.18 & & & & & & \\
\hline 9 & 0.248 & 1.653 & 96.832 & & & & & & \\
\hline 10 & 0.23 & 1.536 & 98.369 & & & & & & \\
\hline 11 & 0.094 & 0.626 & 98.994 & & & & & & \\
\hline 12 & 0.078 & 0.519 & 99.513 & & & & & & \\
\hline 13 & 0.051 & 0.34 & 99.852 & & & & & & \\
\hline 14 & 0.018 & 0.118 & 99.97 & & & & & & \\
\hline 15 & 0.005 & 0.03 & 100 & & & & & & \\
\hline
\end{tabular}

Figure 1. Gravel diagram (the picture has been modified) (from SPSS software).

Table 4. Total variance explanation.

(From SPSS software). 
Table 5. Component matrix.

\begin{tabular}{cccccc}
\hline & Component matrix & & \\
& \multicolumn{5}{c}{ Composition } \\
\cline { 2 - 6 } & 1 & 2 & 3 & 4 & 5 \\
\hline Return on equity & 0.478 & 0.822 & -0.157 & -0.051 & -0.088 \\
Net interest rate on total assets & 0.582 & 0.763 & -0.186 & -0.026 & -0.034 \\
Gross profit margin & 0.705 & -0.016 & 0.099 & -0.431 & 0.268 \\
Net interest rate on sales & 0.657 & 0.665 & -0.058 & -0.208 & 0.057 \\
Underlying earnings per share & -0.143 & 0.318 & 0.811 & 0.353 & 0.184 \\
(year-on-year growth rate) & & & & & \\
Operating income (year-on-year growth rate) & 0.213 & 0.633 & 0.227 & -0.081 & -0.318 \\
Operating profit (year-on-year growth rate) & -0.101 & 0.285 & 0.858 & 0.279 & 0.141 \\
Accounts receivable turnover & -0.243 & 0.228 & -0.151 & 0.208 & 0.75 \\
Inventory turnover & 0.051 & -0.055 & -0.017 & -0.707 & 0.537 \\
Total asset turnover & -0.389 & 0.388 & -0.505 & 0.461 & 0.022 \\
Current asset turnover & -0.508 & 0.387 & -0.407 & 0.422 & 0.257 \\
Current ratio & 0.877 & -0.278 & -0.02 & 0.278 & 0.052 \\
Quick ratio & 0.842 & -0.311 & -0.004 & 0.352 & 0.067 \\
Cash ratio & 0.828 & -0.287 & 0.013 & 0.354 & 0.142 \\
Asset-liability ratio & -0.664 & 0.261 & 0.188 & -0.335 & -0.026 \\
\hline
\end{tabular}

(From SPSS software).

Among them, $Z 1$ is the comprehensive index of short-term solvency of the first principal component listed company. In the formula, $X 12$ current ratio, $X 13$ quick ratio and $X 14$ cash ratio take up a large proportion.

$$
\begin{aligned}
Z 2= & 0.822 X 1+0.763 X 2-0.016 X 3+0.665 X 4+0.318 X 5 \\
& +0.633 X 6+0.285 X 7+0.228 X 8-0.055 X 9+0.388 X 10 \\
& +0.387 X 11-0.278 X 12-0.311 X 13-0.287 X 14+0.261 X 15
\end{aligned}
$$

Among them, $Z 2$ is the comprehensive index of profitability of listed companies with the second principal component, where, the return on equity of $X 1$ and the net interest rate of total assets of $X 2$ account for a large proportion.

$$
\begin{aligned}
Z 3= & -0.157 X 1-0.186 X 2+0.099 X 3-0.058 X 4+0.811 X 5 \\
& +0.227 X 6+0.858 X 7-0.151 X 8-0.017 X 9-0.505 X 10 \\
& -0.407 X 11-0.02 X 12-0.004 X 13+0.013 X 14+0.188 X 15
\end{aligned}
$$

Among them, $Z 3$ is the comprehensive index of the development ability of the third principal component listed company, where $X 5$ basic earnings per share and $X 7$ operating profit account for a large proportion.

$$
\begin{aligned}
Z 4= & -0.051 X 1-0.026 X 2-0.431 X 3-0.208 X 4+0.353 X 5 \\
& -0.081 X 6+0.279 X 7+0.208 X 8-0.707 X 9+0.461 X 10 \\
& +0.422 X 11+0.278 X 12+0.352 X 13+0.354 X 14-0.335 X 15
\end{aligned}
$$


Among them, $Z 4$ is the comprehensive index of the operating capacity of the fourth principal component listed company. In the formula, the total asset turnover ratio of $X 10$ and current asset turnover ratio of $X 11$ account for a large proportion.

$$
\begin{aligned}
Z 5= & -0.088 X 1-0.034 X 2+0.268 X 3+0.057 X 4+0.184 X 5 \\
& -0.318 X 6+0.141 X 7+0.75 X 8+0.537 X 9+0.022 X 10 \\
& +0.257 X 11+0.052 X 12+0.067 X 13+0.142 X 14-0.026 X 15
\end{aligned}
$$

Among them, $Z 5$ is the comprehensive index of the operating capacity of the listed company with the fifth principal component. In the formula, the two indexes of $X 8$ receivables turnover ratio and $X 9$ inventory turnover ratio account for a large proportion.

2) With the variance contribution rate corresponding to each principal component as the weight, the weighted sum is used to obtain the urban economic vitality evaluation system model:

$$
F=0.297 Z 1+0.285 Z 2+0.159 Z 3+0.153 Z 4+0.133 Z 5
$$

$F$ for the financial performance of listed companies, $Z 1, Z 2, Z 3, Z 4$ and $Z 5$ respectively as the first principal component of the listed company's short-term debt paying ability comprehensive index, the second principal component comprehensive index, the profitability of the listed company's third principal component development ability of comprehensive index of listed companies, the fourth, five principal component comprehensive index of the operation ability of listed companies. Where, the financial performance of listed companies can be mainly measured by the short-term debt paying ability of $30.993 \%$ of listed companies, the profitability of $19.737 \%$ of listed companies, the development ability of $13.311 \%$ of listed companies and the operating ability of $12.091 \%$ and $7.894 \%$ of listed companies.

\section{Conclusion}

In building enterprise in the process of financial performance evaluation system, it is needed to consider many factors, and break the original single evaluation index model. This paper uses principal component analysis (PCA), using the "dimension" thought, on the premise of less loss of information of multiple indicators into several comprehensive indexes, respectively on corporate financial performance evaluation model set up in Anhui Province, and simplifies the system structure. Through the principal component analysis above, it can be found that, among the solvency, profitability, development ability and operation ability of a company, the short-term solvency of the company has a greater impact on the company's financial performance, while the development ability and operation ability have a relatively small impact on the company's financial performance evaluation. Using principal component analysis and statistical methods to evaluate enterprise's financial position effect, can make the enterprise be able to make scientific and rational judgment on own finances, to avoid the artificially determined weighting the defects in the current evaluation methods, and at the 
same time, encourage enterprises to improve business performance, to improve the financial situation providing more feasible ideas and thoughts. Hope can help enterprises to obtain more long-term stable development.

\section{Conflicts of Interest}

The authors declare no conflicts of interest regarding the publication of this paper.

\section{References}

Cheng, L. M., Zhang, M. M., \& Yang, W. Q. (2020). Research on the Influence of SF Express Group on Corporate Financial Performance after Backdoor Listing-Based on EVA Evaluation System. China Business Theory, No. 1, 50-51.

Cui, M. Y., \& Huang, Q. (2019). Establishment of Financial Risk Assessment System and Early Warning Model under Supply-Side Reform-A Case Study of the Energy Industry. Modern Business, No. 4, 124-125.

Li, H. R., \& Wang, H. H. (2020). Financial Performance Evaluation of port Listed Companies Based on Global Principal Component Analysis. Horizon of Land Bridge, No. 3, 71-75.

Liu, J. F., \& Duan, R. Y. (2020). A Microprobe into the Financial Performance Evaluation Index System of Enterprises in the New Era. National Circulation Economy, No. 2, 182-183.

Liu, X. D., Li, Q., Li, Y., \& Tao, X. (2020). Construction and Application of Enterprise Financial Performance Evaluation System Based on the Concept of Green Development. China Township Enterprise Accounting, No. 1, 80-83.

Lu, Y., Wang, J. J., Gao, K. L., \& Liu, X. H. (2019). Research on the Impact of Enterprise R\&D Investment on Enterprise Growth. Foreign Trade and Economic Cooperation, No. 12, 114-117+156.

Xie, H., Xue, Q. Y., \& Zhu, J. M. (2019). Study on Evaluation of Financing Ability of Small and Medium-Sized Enterprises in Jiangxi Province Based on PA-Multivariate Regression. Journal of Mianyang Normal University, 38, 25-32.

Yang, Z. H., Wang, R., Li, H., Zhang, L. T., \& Wang, J. W. (2016). Research on Evaluation System of Financial Index of State-Owned Enterprises Based on Principal Component Analysis. Contemporary Accounting, No. 11, 69-70.

Zhao, J. J. (2019). Strategy-Based Financial Performance Evaluation of Enterprises-A Case Study of Tsingtao Beer Co., LTD. Taxation, 13, 47-48+53. 